\title{
Assessment of the Tectonic Activity in Northwestern Part of the Zagros Mountains, Northeastern Iraq by Using Geomorphic Indices
}

\author{
Ziyad Elias • Varoujan K. Sissakian • Nadhir Al-Ansari $(\mathbb{D}$
}

Received: 14 February 2019/Accepted: 26 March 2019/Published online: 8 April 2019

(C) The Author(s) 2019

\begin{abstract}
The Tectonic Activity of regions with active tectonics can be assessed by using of the geomorphic indices. Six Geomorphic indices including stream-gradient index $(\boldsymbol{S L})$, drainage basin asymmetry $(\boldsymbol{A} \boldsymbol{f})$, drainage basin shape (Bs), hypsometric integral (Hi), valley floor width-valley height ratio (Vf), and mountain-front sinuosity (Smf) were calculated using GIS technique in Kifri Chai Basin; northeast Iraq, which belongs to the Western Zagros Mountain. The basin was divided into eighteen subbasins depending on the 4th, 5th and 6th stream orders of the drainage within Kirfi Basin. It was found that the SL, Af, Bs, Hi, Vf, and $\boldsymbol{S m f}(\boldsymbol{J})$ values are uniform and exhibit almost the same classes. However, few exceptions occur, especially in $\boldsymbol{B} \boldsymbol{s}$ values, but the exceptional values do not influence significantly on the acquired results, in each of the eighteen sub-basin.
\end{abstract}

\footnotetext{
Z. Elias

Geomorphic Researcher, Hannover, Germany

e-mail: ziyadelias@yahoo.com

\section{K. Sissakian}

University of Kurdistan, Hewler, KRG, Iraq

e-mail: f.kajeek@ukh.edu.krd;

varoujan49@yahoo.com

V. K. Sissakian

Private Consultant Geologist, Erbīl, Iraq

N. Al-Ansari $(\bowtie)$

Lulea University of Technology, Luleå, Sweden

e-mail: Nadhir.alansari@1tu.se
}

From these indices the relative active tectonics index value (Iat) was determined. The results of average Iat values (2.35) showed that the tectonic activity in the whole basin is Moderate. Moreover, an attempt was carried out to compare the regional Neotectonic activity with the relative tectonic activity in the basin. The results showed that there is a positive relation between the two comparatives; especially the subsidence amount and scored relative tectonic activity.

Keywords Geomorphic indices - Tectonic activity · Neotectonic $\cdot$ Western Zagros · Iraq

\section{Introduction}

The phenomenon of tectonic movements is the best recognized in the history of basin development. Therefore, landscape analyses of such areas and studies of drainage networks, in particular, provide insights into current tectonic processes and their activities. Attempts to quantify tectonic deformation from landscape analyses have been performed for decades (e.g., Bull and McFadden 1977; Rockwell et al. 1985; Merritts and Vincent 1989; Burbank 1992; Burbank and Anderson 2001; Keller and Pinter 2002; Crosby and Sheehan 2006; Wobus et al. 2010, 2012; Kirby and Whipple 2012). The rapid development of GIS techniques and the constant advancement in 
digital elevation model (DEM) quality and access provide significant and efficient tools to compute, calculate and analyze geomorphic indices across areas of various environments and scales (e.g., Keller et al. 1982; Ramírez-Herrera 1998; Kirby et al. 2003; Gürbüz and Gürer 2008; Arrowsmith and Zielke 2009; Gasparini and Whipple 2014). However, studies that use geomorphic indices to explore the relative activity of tectonic processes in the fore-arc regions of active subduction zones are limited and/or use only one or two indices (e.g., Wells et al. 1988; Fisher et al. 1998; Morell et al. 2008; Rehak et al. 2008).

Active deformation in the Zagros Mountains is caused by the northward motion of the Arabian Plate with respect to Eurasian Plate, which occurs at a rate of $25 \mathrm{~mm}$ year ${ }^{-1}$ at longitude $56^{\circ} \mathrm{E}$ (Ramsey et al. 2008). The style of deformation appears to vary along the strike of the Zagros Mountain Range. In the NW (Dezful), N-S shortening between Arabia and Eurasia plates is accommodated on a spatially separated system of NW trending right-lateral strike-slip and thrust faults (Ramsey et al. 2008). It is worth to mention that Dezful Embayment in Iraq is called Kirkuk Embayment (Fouad 2012).

Recent works have been carried out on the tectonic activity; among them are Verrios et al. (2004), they performed their study in Greece. El-Hamdouni et al. (2008) performed their study in South of Spain. In Iran many studies were performed, Ghassemi (2005) has commented on the fold growth in NE Alborz, Dehbozorgi et al. (2010) in central Zagros Range, Mumipour and Najad (2011) in south of Iran, Toudeshki and Arian (2011) in northwest Iran, Habibi and Gharibreza (2015) in central part of Iran, and Mosavi and Arian (2015) in northeast of Iran. All those studies have used the geomorphological indices to indicate the tectonic activity in their studied areas.

The above mentioned review for a part of the existing literature indicates that the knowledge about the effects of tectonic movements upon river valley forms; fluvial processes are not sufficiently investigated in the Iraqi territory where these issues are very rarely studied and require more detailed studies.

Kfiri Chai Basin is located in the north-eastern part of Iraq (Fig. 1). The coverage area is $2821.15 \mathrm{~km}^{2}$. The Kifri Chai Basin was divided into eighteen subbasins and called them in this study as Sub-basins No. 1 to No. 18.
The main aim of the current study is to indicate the tectonic activity of Kifri Chai Basin which is part of the Western Zagros Range. Moreover, the relative tectonic activity was compared with the regional Neotectonic movements in Kifri Chai Basin to indicate the relation between both aspects.

\subsection{Geological and Neotectonic Setting}

The studied area is located within the Low Folded Zone of the Outer Platform, which belongs to the Arabian Plate (Fouad 2012). Four anticlines occur in the study area; these are from the north to south: Kalar, Pulkhana, Qumar and Gillabat (Fig. 2).

All the anticlines exhibit thrusting, where their northeastern limbs are thrusted over their southwestern limbs causing their disappearance and the anticlinal axis (Sissakian 1978; Youkhanna and Hradecky 1978). The youngest exposed formation is the Bai Hassan Formation. This means that the thrusting had occurred after the Middle Pleistocene; accordingly, it is considered as a neotectonic movement (Obruchev 1948).

The exposed formations in the Kifri Chai Basin are:

1. Fatha Formation (Middle Miocene): Consists mainly of reddish brown claystone, marl, limestone and gypsum and cyclic nature.

2. Injana Formation (Upper Miocene): Consists mainly of reddish brown sandsotone, siltstone and claystone in cyclic nature.

3. Mukdadiya Formation (Upper Miocene-Pliocene): Consists of greyish sandsotone, siltstone and claystone in cyclic nature. With some pebbly sandstone.

4. Bai Hassan Formation (Pliocene-Pleistocene): Consists mainly of conglomerate, reddish brown claystone in cyclic nature, with some sandstone beds.

5. Quaternary sediments: Mainly valley fill, flood plain and slope sediments, besides river terraces

The neotectonic activity in Iraq is considered since the Upper Miocene, when the marine environment was terminated and continental depositional environment prevailed. This assumption is based on Obruchev (1948) and Atomenergoexport (1985). Sissakian and Deikran (1998) compiled the Neotectonic Map of Iraq, which is based on the contact between the Fatha Formation (Middle Miocene) and the Injana 


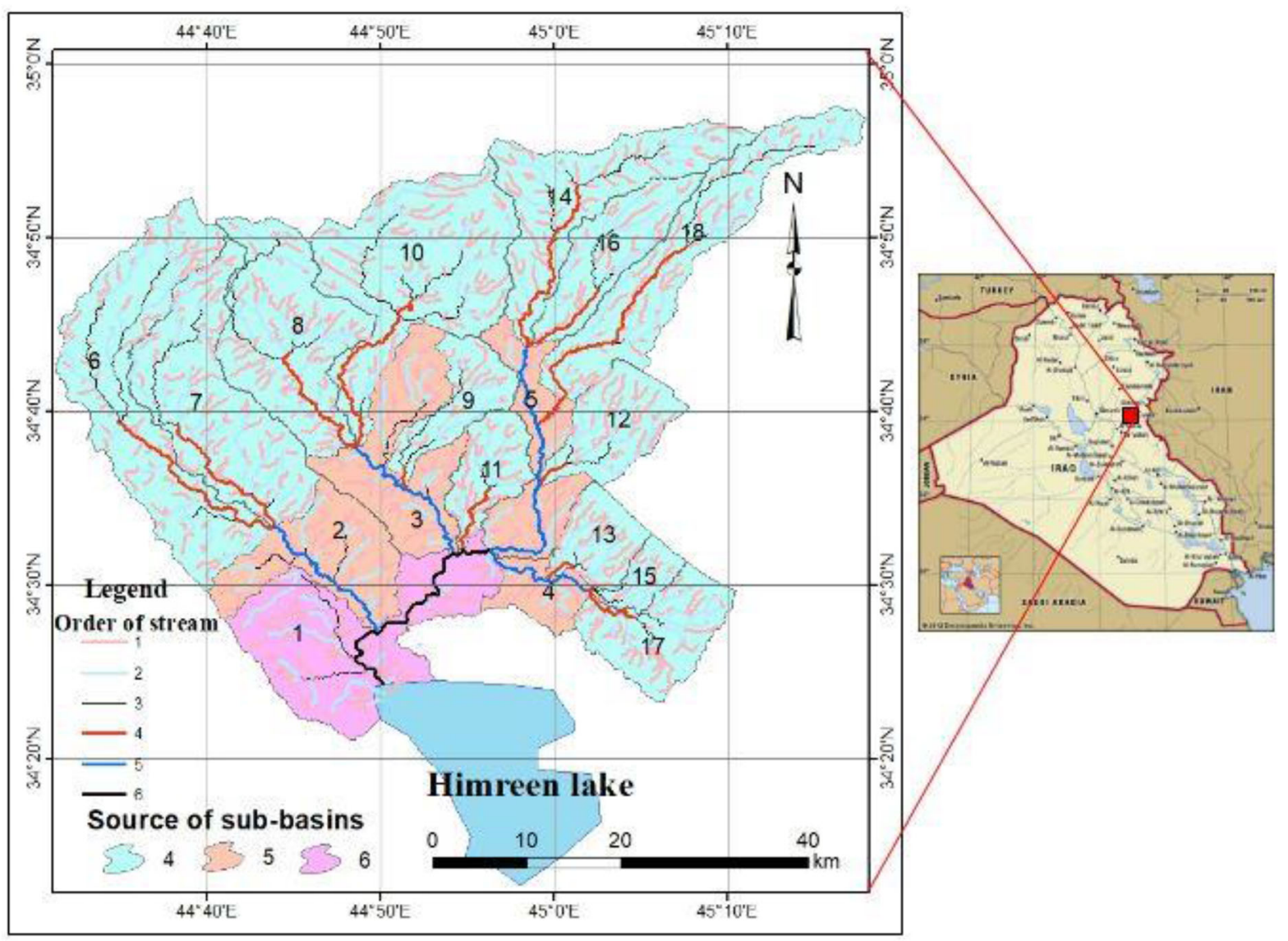

Fig. 1 Location map of the studied area and the 18 sub-basins

Formation (Upper Miocene) as compared to the present topography.

\subsection{Data Used and Methodology}

This study was carried out using Radar Topography Mission (SRTM) data with extensive use of previously published geological, and Neotectonic maps. The borders of the sub- basins were delineated using SRTM image that has a ground resolution of 3-arc-second $(90 \mathrm{~m})$ and a vertical resolution of approximately $10 \mathrm{~m}$.

Kifri Chai Basin was divided into eighteen subbasins according to the ordering of the streams, using Straller's stream ordering method. The stream order was generated up to 6th orders using the stream ordering module of ArcGIS. The eighteen sub-basins are located depending on the 4th, 5th, and 6th stream orders. The coverage area of the basin was extracted from the DEM map using the basin extraction tool of ArcGIS which gives accurate size and shape of each sub basin.

\section{Geomorphic Indices}

Six geomorphic indices were used to estimate the relative tectonic activity in Kifri Chai Basin. For each index, a map was constructed based on DEM image which shows the classes of each index at each subbasin. The measured six geomorphic indices at each sub-basin are mentioned hereinafter. The acquired values (Table 1) and classes are according to ElHamdouni et al. (2008) and enclosed references.

\subsection{Stream-Gradient Index (Sl)}

This index shows the relation between the length of a valley and its gradient, it is defined as:

$\mathrm{SL}=(\Delta \mathrm{H} / \Delta \mathrm{L}) * \mathrm{~L}$

where $\boldsymbol{S} \boldsymbol{L}$ denotes the Stream length gradient index, $\Delta \mathbf{H} / \mathbf{\Delta L}$ denotes the channel slope or gradient of the reach $(\Delta \mathrm{H}$ is the change in elevation of the reach and 


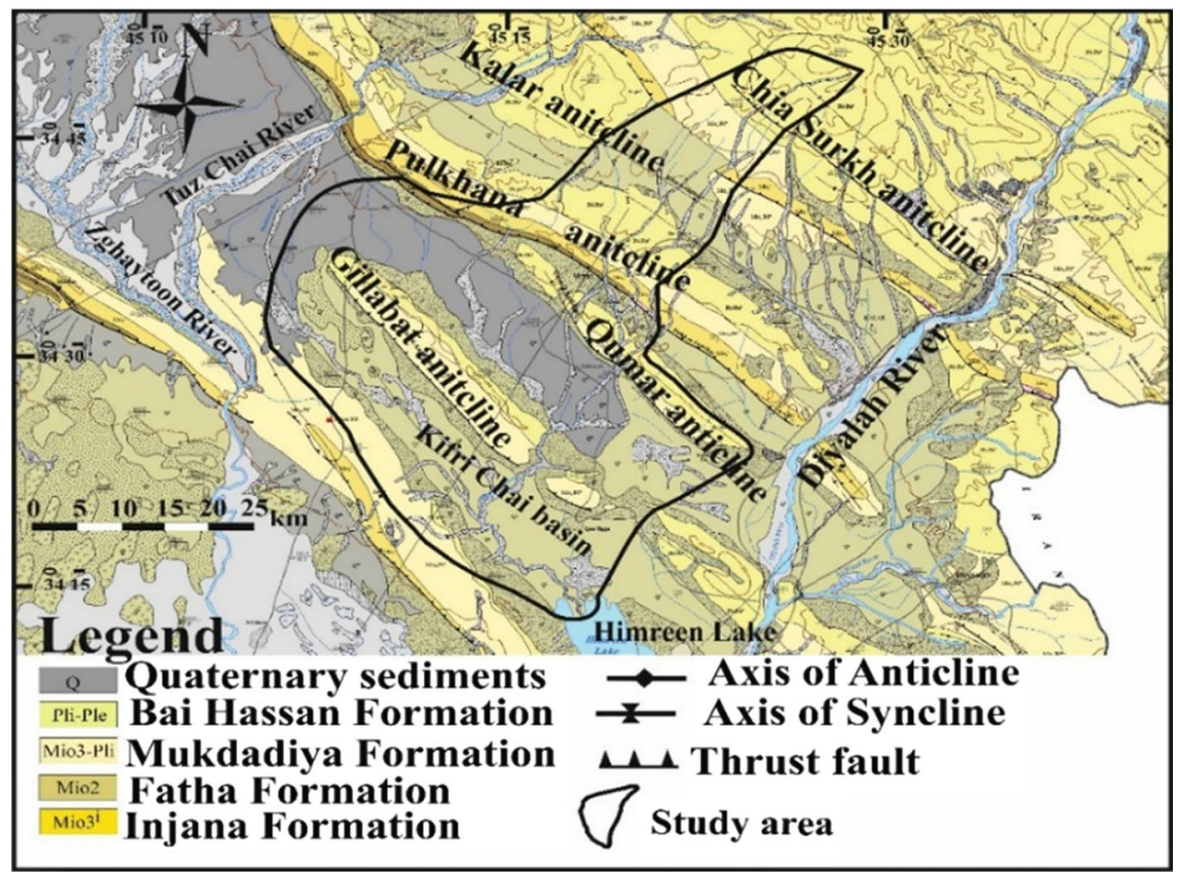

Fig. 2 Geological map of the studied area and near surroundings (After Sissakian and Fouad 2014; Barwary and Slewa 2014a, b)

Table 1 Values of geomorphic indices of the eighteen sub basins

\begin{tabular}{|c|c|c|c|c|c|c|c|c|}
\hline Sub-basin no & Stream order & Sub basin area $\left(\mathrm{km}^{2}\right)$ & Sl & Af & Bs & $\mathrm{Hi}$ & Vf & Smf \\
\hline 1 & 6 & 521.34 & 90 & 39.28 & 2.78 & 0.14 & 2.8 & 2.3 \\
\hline 2 & 5 & 129.96 & 160 & 41.89 & 2.18 & 0.16 & 3.2 & 1.6 \\
\hline 3 & 5 & 152.76 & 220 & 47.86 & 5.6 & 0.19 & 9.7 & 1.2 \\
\hline 4 & 5 & 46.75 & 49 & 27.98 & 2.17 & 0.10 & 9.1 & $*$ \\
\hline 5 & 5 & 105.59 & 257 & 59.06 & 15.96 & 0.29 & 7.7 & 1.2 \\
\hline 6 & 4 & 274.49 & 180 & 48.5 & 5.5 & 0.13 & 2.3 & 2.4 \\
\hline 7 & 4 & 220.82 & 220 & 36.48 & 4.96 & 0.13 & 2.6 & 2.2 \\
\hline 8 & 4 & 204.81 & 280 & 46.06 & 2.83 & 0.15 & 2 & 1.2 \\
\hline 9 & 4 & 69.15 & 240 & 36.22 & 3.9 & 0.16 & 7.2 & 1.3 \\
\hline 10 & 4 & 273.75 & 700 & 53.75 & 2.78 & 0.26 & 0.9 & 2.5 \\
\hline 11 & 4 & 64.51 & 200 & 61.74 & 3.27 & 0.16 & 13.9 & $*$ \\
\hline 12 & 4 & 90.10 & 280 & 38.93 & 2.16 & 0.22 & 5.1 & 1.3 \\
\hline 13 & 4 & 58.82 & 200 & 53.23 & 2.04 & 0.12 & 11.7 & 1.3 \\
\hline 14 & 4 & 176.87 & 800 & 73.39 & 5.68 & 0.28 & 4.0 & 2.8 \\
\hline 15 & 4 & 30.08 & 160 & 50.99 & 3.33 & 0.11 & 4.0 & 1.4 \\
\hline 16 & 4 & 99.70 & 400 & 62.89 & 5.51 & 0.25 & 10.9 & 2.7 \\
\hline 17 & 4 & 106.47 & 140 & 31.01 & 2.2 & 0.08 & 12.2 & 1.1 \\
\hline 18 & 4 & 195.18 & 1000 & 50.18 & 9.18 & 0.32 & 8.6 & 1.9 \\
\hline Average & & & 309.8 & 47.75 & 4.56 & 0.18 & 6.55 & 1.8 \\
\hline
\end{tabular}

*No mountain front exists in the sub-basin 
$\Delta \mathrm{L}$ is the length of the reach), and $\mathbf{L}$ denotes the total channel length from the point of interest (Hack 1973). The values of the $\mathbf{S I}$ in the eighteen sub-basins are assigned in Table 1. The (SI) Index is classified into three tectonic activity classes: (Class 1) High ( $\boldsymbol{S l}>500)$, (Class 2) Moderate $(300 \geq \boldsymbol{S l}<500)$, and (Class 3) Low $(\boldsymbol{S} \boldsymbol{l}<300)$. The acquired average $\mathrm{Sl}$ value is 309.8 which indicates Class 2, meaning Moderate tectonic activity, the classes of the eighteen sub-basins are shown in Fig. 3.

\subsection{Asymmetric Factor $(A f)$}

The asymmetric factor ( $\boldsymbol{A} \boldsymbol{f})$ was used to evaluate the tectonics activity at a drainage basin scale. Its area of application is relatively large (Hare and Gardner 1985; Keller and Pinter 2002). The $\boldsymbol{A f}$ index is formulated as follows:

Af $=100 *(\mathrm{Ar} / \mathrm{At})$.

where Ar represents the area on the right side of the trunk stream, and At represents the total area of the drainage basin.

The values of the Af in the eighteen sub-basins are assigned in Table 1. The Asymmetric Factor (Af) is classified into three classes: (Class 1) (Af $<35$ or Af $>65)$, (Class 2) $(57<$ Af $<65$ or $35<$ Af $<43)$, and (Class 3) $(43<$ Af $<57)$. The average Af value is 47.7 which indicates Class 3 , and the classes of the eighteen sub-basins are shown in Fig. 3.

\subsection{Basin Shape Index $(B s)$}

This index indicated the shape of the basin and its relation with the relative tectonics. This index is identified as:

$\mathrm{Bs}=\mathrm{Bl} / \mathrm{Bw}$

where $\mathbf{B l}$ is the length of a basin measured from the headwaters point to the mouth of the sub basin, and Bw is the width of sub basin measured at its widest point.

The basin shape index (Bs) includes three classes: (Class 1) Elongate basin with $\boldsymbol{B s}>4$; (Class 2) Semielongate basin with $3 \leq \boldsymbol{B} \boldsymbol{s}<4$; and (Class 3) Circular basin with $\boldsymbol{B} s<3$. The values of the Bs in the eighteen sub-basins are assigned in Table 1 . The average Bs value is 4.56 which indicates Class 1 . The classes of the eighteen sub-basins are shown in Fig. 4.
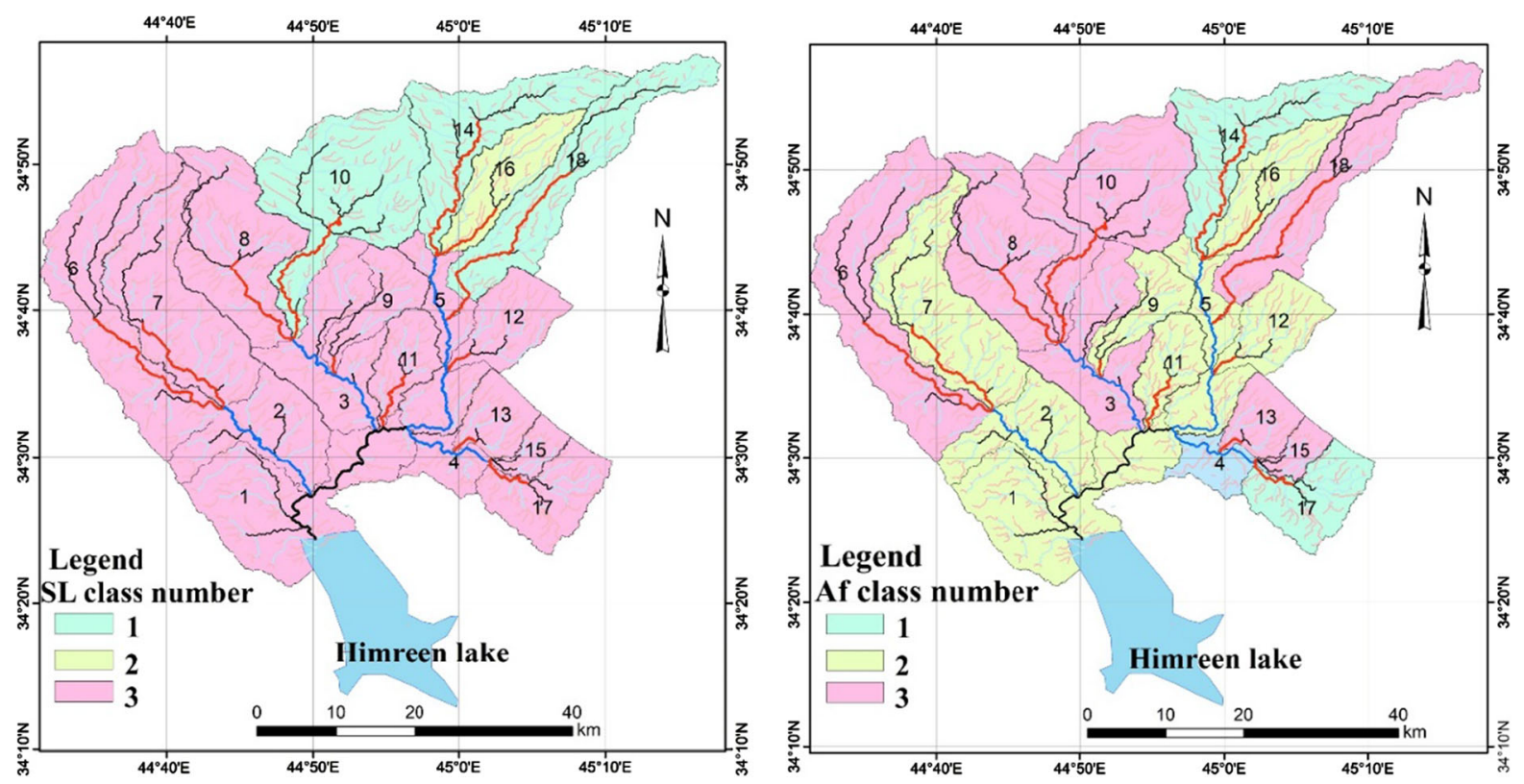

Fig. 3 Map of the eighteen sub-basins classes. (Left) Stream Gradient Index (Sl), (Right) Asymmetric Factor (Af) 

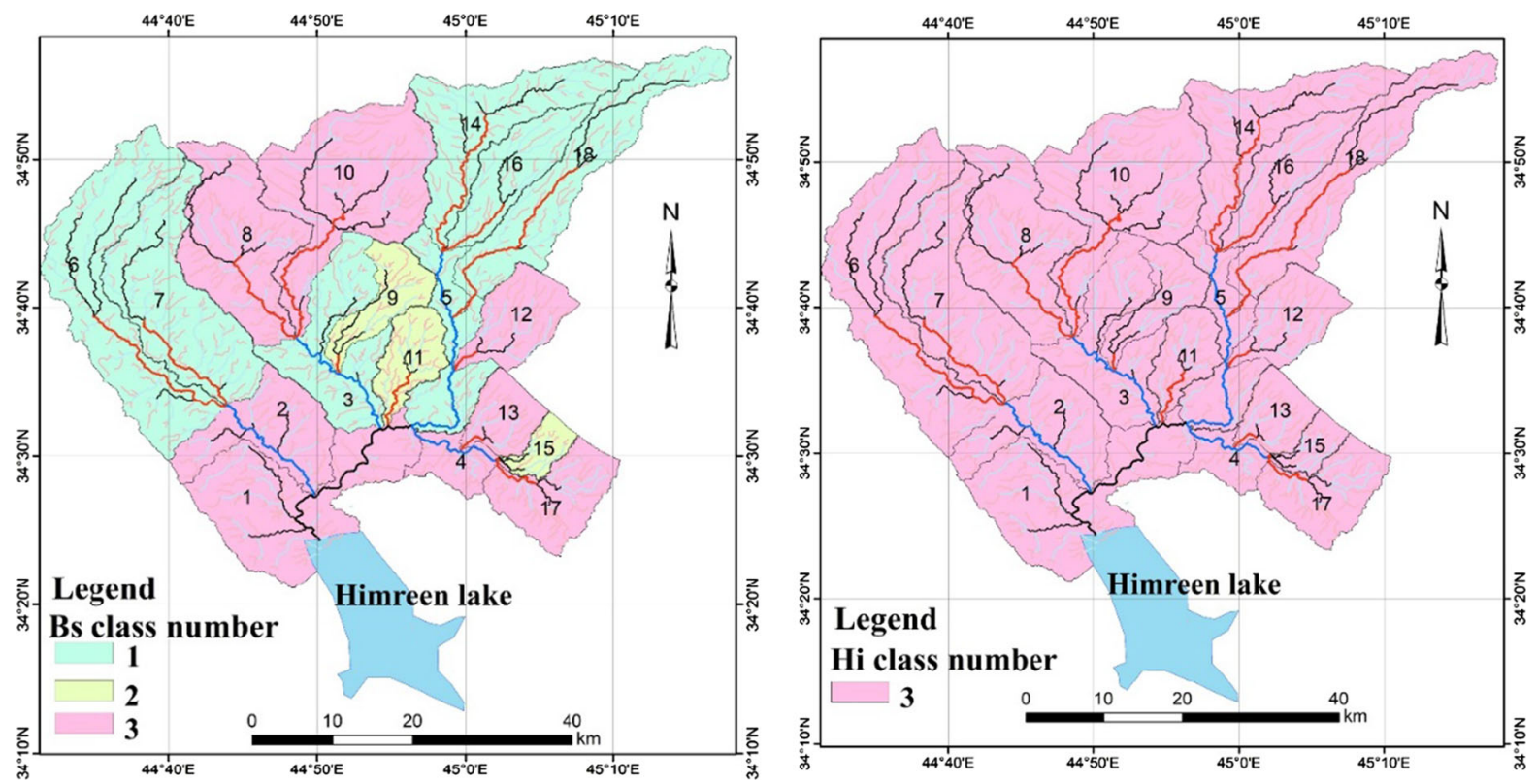

Fig. 4 Map of the eighteen sub-basins classes. (Left) Basin Shape Index (Bs), (Right) Hypsometric Integral (Hi)

\subsection{Hypsometric Integral (Hi)}

The hypsometric integral (Hi) describes the relative distribution of elevation in a given area of a landscape, particularly a drainage basin (Strahler 1952). The index is defined as the relative area below the hypsometric curve and thus expresses the volume of a basin that has not been eroded. A simple equation to approximately calculate the index is (Pike and Wilson 1971; Mayer 1990; Keller and Pinter 2002):

$\begin{aligned} \mathrm{Hi}= & (\text { average elev. }- \text { min. elev. }) /(\text { max. elev. } \\ & - \text { min. elev. })\end{aligned}$

The Hypsometric Integral index (Hi) is classified into three classes: (Class 1) $(\mathbf{H i} \geq 0.5),($ Class 2) $(0.4 \leq \mathbf{H i}<0.5)$ and $($ Class 3$)(\mathbf{H i}<0.4)$. (Table 1$)$. The values of the Hi in the eighteen sub-basins are assigned in Table 1. The average Hi value is 0.18 , which indicates Class 3. The classes of the eighteen sub-basins are shown in Fig. 4.

\subsection{Ratio of Valley Floor Width to Valley Height (Vf)}

This index gives the ration between the width of the valley floor and the height of the valley in certain area within a valley, it is a good indication about the erosion and tectonic activity. This parameter is calculated as:

$\mathrm{Vf}=2 \mathrm{~V}_{\mathrm{fw}} /\left[\left(\mathrm{E}_{\mathrm{ld}}-\mathrm{E}_{\mathrm{sc}}\right)+\left(\mathrm{E}_{\mathrm{rd}}-\mathrm{E}_{\mathrm{sc}}\right)\right]$

where Vf denotes the valley floor width to valley height ratio, $\mathbf{V}_{\mathbf{f w}}$ denotes the width of the valley floor, $\mathbf{E}_{\text {Id }}$ and $\mathbf{E}_{\text {rd }}$ stand for elevations of the left and right valley divides, respectively $\mathbf{E}_{\mathbf{s c}}$ denotes the elevation of the valley floor (Keller and Pinter 2002; Cuong and Zuchiewicz 2001).

The Vf index is divided into three classes: (Class 1) $(\boldsymbol{V} \boldsymbol{f} \leq 0.5)$, (Class 2) $(0.5 \leq \boldsymbol{V} \boldsymbol{f}<1.0)$ and $($ Class 3) $(\boldsymbol{V} \boldsymbol{f} \geq 1)$. The valleys are often narrow upstream from the mountain front (Ramírez-Herrera 1998). The indicated values of $\boldsymbol{V} \boldsymbol{f}$ are assigned in Table 1. The acquired average Vf value is 6.55 which indicates Class 3. The classes of the eighteen sub-basins are shown in Fig. 5.

\subsection{Mountain-Front Sinuosity Index (Smf) (J)}

The index reflects the balance between erosion forces that tend to cut embayment into a mountain front and tectonic forces that tend to produce a straight mountain front (Verrios et al. 2004).

Mountain front sinuosity index is defined as: 

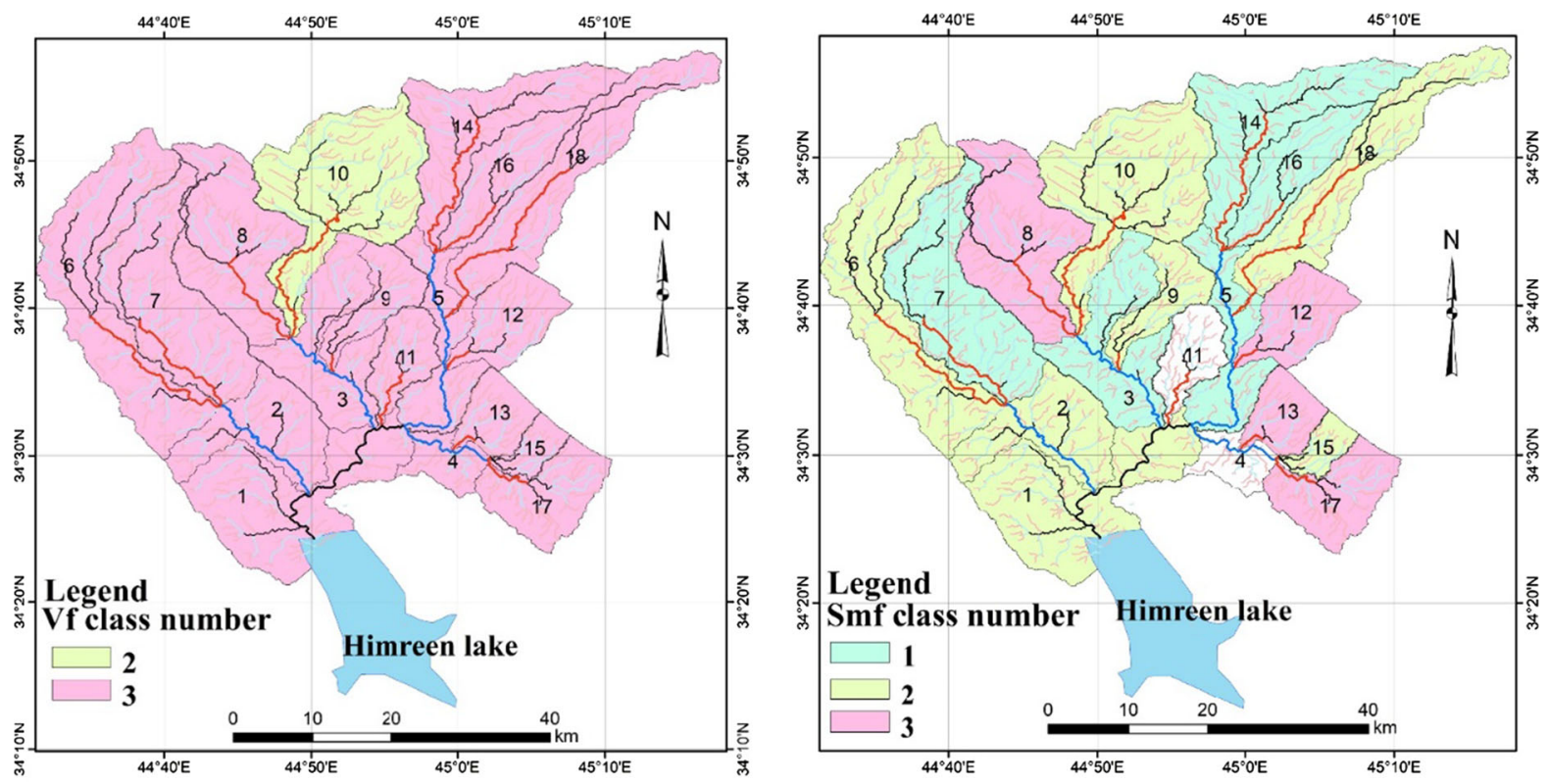

Fig. 5 Map of the eighteen sub-basins classes. (Left) Ratio of Valley Floor Width to Valley Height (Vf), (Right) Mountain-front sinuosity index (Smf)

$\mathrm{S}_{\mathrm{mf}}=\mathrm{L}_{\mathrm{mf}} / \mathrm{L}_{\mathrm{s}}$

where $\mathrm{S}_{\mathrm{mf}}$ denotes the mountain front sinuosity; $\mathrm{L}_{\mathrm{mf}}$ denotes the length of the mountain front along the foot of the mountain at the pronounced break in slope, and $\mathrm{L}_{\mathrm{s}}$ denotes the straight-line length of the mountain front.

The values of the $\mathbf{J}$ in the eighteen sub-basins are assigned in Table 1 and the classes are presented in Fig. 5. The measured mountain-fronts are shown in Fig. 6. The Mountain Front Sinuosity Index $(\boldsymbol{J})$ is divided into three classes: (Class 1) High, $\boldsymbol{J}=1.0$ to 1.5, (Class 2) Moderate, $\boldsymbol{J}=1.5$ to 2.5 , and (Class 3) Low, $\boldsymbol{J}>2.5$ (El-Hamdouni et al. 2008). The acquired average Smf value is 1.8 which indicates Class 2 .

\section{Evaluation of Relative Tectonic Activity (Iat)}

We have used the average of the six measured geomorphic indices to indicate the relative tectonic activity (Iat), following El-Hamdouni et al. (2008). This index represents a summary and average of the given geomorphic indices, it is calculated as follows (Habibi and Gharibreza 2015):

Iat $=\mathrm{S} / \mathrm{N}$, where $\mathrm{S}$ represents the sum of previous indices, $\mathrm{N}$ represents the number of selected indices.

The values of the Iat index are divided into four classes (El-Hamdouni et al. 2008) to define the degree of active tectonics: Class $1-$ Very high $(1.0 \leq$ Iat $<$ 1.5), Class 2-High $(1.5 \leq$ Iat $<2.0)$, Class $3-$ Moderate $(2.0 \leq$ Iat $<2.5)$, and Class 4-Low (Iat $>2.5$ ). The Iat values in the eighteen sub-basins range from 2.00 to 2.66 and the average Iat value is 2.35 (Table 2), which indicates Class 3; meaning Moderate tectonic activity. The Iat classes of the eighteen sub-basins are presented in Fig. 6.

\section{Relation Between Regional Neotectonic Activity and Local Tectonic Activity}

The Kifri Chai Basin represents the deepest subsided areas within the whole Zagros Foreland Basin inside the Iraqi territory. The depth of the Middle-Upper Miocene contact reaches up to $3000 \mathrm{~m}$ below the sea level (Table 3 and Fig. 7). However, the maximum up-warped reaches $250 \mathrm{~m}$ (a.s.l.) and the Zero Line (Fig. 7) which represents the Middle-Upper Miocene sea level runs in the middle part of the basin. 

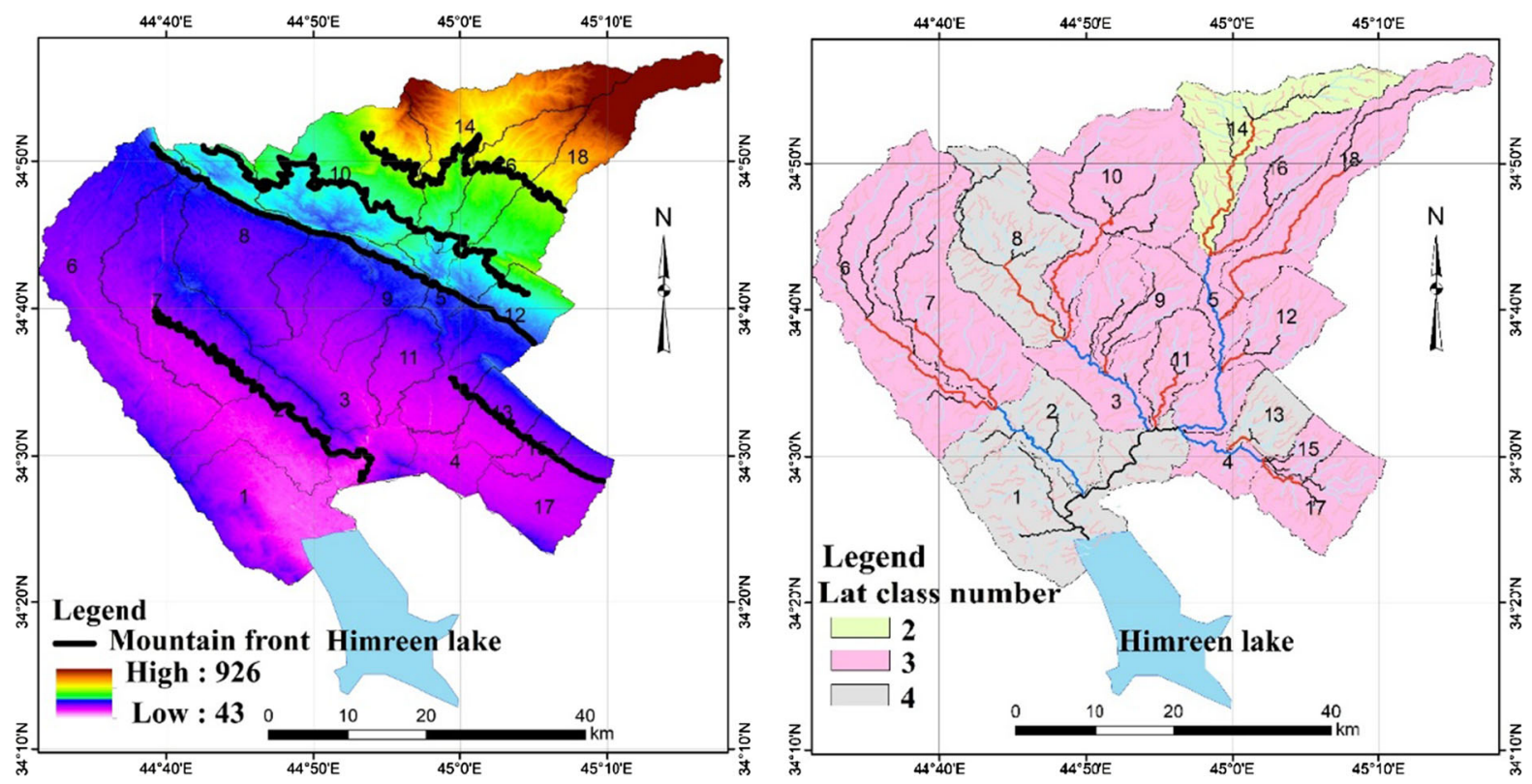

Fig. 6 (Left) The measured Mountain Fronts (J) within the eighteen sub-basins, (Right) Map of Relative Tectonic Activity (Iat) Classes of the eighteen sub-basins

Table 2 Classes of the geomorphic indices with Iat values and classes, and tectonic activity of the eighteen sub-basins

\begin{tabular}{|c|c|c|c|c|c|c|c|c|c|c|}
\hline \multirow[t]{2}{*}{ Sub-basin no } & \multirow[t]{2}{*}{ Stream order } & \multirow{2}{*}{$\begin{array}{l}\text { Sl } \\
\text { Class }\end{array}$} & \multirow[t]{2}{*}{ Af } & \multirow[t]{2}{*}{ Bs } & \multirow[t]{2}{*}{$\mathrm{Hi}$} & \multirow[t]{2}{*}{ Vf } & \multirow[t]{2}{*}{ Smf } & \multicolumn{2}{|l|}{ Lat } & \multirow[t]{2}{*}{ Tectonic activity } \\
\hline & & & & & & & & Value & Class & \\
\hline 1 & 6 & 3 & 2 & 3 & 3 & 3 & 2 & 2.66 & 4 & Low \\
\hline 2 & 5 & 3 & 2 & 3 & 3 & 3 & 2 & 2.66 & 4 & Low \\
\hline 3 & 5 & 3 & 3 & 1 & 3 & 3 & 1 & 2.30 & 3 & Moderate \\
\hline 4 & 5 & 3 & 1 & 3 & 3 & 3 & $*$ & 2.15 & 3 & Moderate \\
\hline 5 & 5 & 3 & 2 & 1 & 3 & 3 & 1 & 2.16 & 3 & Moderate \\
\hline 6 & 4 & 3 & 3 & 1 & 3 & 3 & 2 & 2.50 & 3 & Moderate \\
\hline 7 & 4 & 3 & 2 & 1 & 3 & 3 & 1 & 2.16 & 3 & Moderate \\
\hline 8 & 4 & 3 & 3 & 3 & 3 & 3 & 1 & 2.66 & 4 & Low \\
\hline 9 & 4 & 3 & 2 & 2 & 3 & 3 & 1 & 2.30 & 3 & Moderate \\
\hline 10 & 4 & 1 & 3 & 3 & 3 & 2 & 2 & 2.30 & 3 & Moderate \\
\hline 11 & 4 & 3 & 2 & 2 & 2 & 3 & $*$ & 2.16 & 3 & Moderate \\
\hline 12 & 4 & 3 & 2 & 3 & 3 & 3 & 1 & 2.50 & 3 & Moderate \\
\hline 13 & 4 & 3 & 3 & 3 & 3 & 3 & 1 & 2.60 & 4 & Low \\
\hline 14 & 4 & 1 & 1 & 1 & 3 & 3 & 3 & 2.00 & 2 & High \\
\hline 15 & 4 & 3 & 3 & 2 & 3 & 3 & 1 & 2.50 & 3 & Moderate \\
\hline 16 & 4 & 2 & 2 & 1 & 3 & 3 & 3 & 2.30 & 3 & Moderate \\
\hline 17 & 4 & 3 & 1 & 3 & 3 & 3 & 1 & 2.30 & 3 & Moderate \\
\hline 18 & 4 & 1 & 3 & 1 & 3 & 3 & 2 & 2.16 & 3 & Moderate \\
\hline Average & & 2.66 & 2.20 & 2.05 & 2.94 & 2.94 & 1.56 & 2.35 & 3 & Moderate \\
\hline
\end{tabular}

*Means there is no Mountain Front in the sub-basin 
Table 3 Neotectonic data and Iat values of the 18 sub-basins within Kifri Chai Basin

\begin{tabular}{|c|c|c|c|c|c|c|c|c|c|c|c|c|c|c|}
\hline \multirow{5}{*}{$\begin{array}{l}\text { Sub- } \\
\text { basin } \\
\text { No. }\end{array}$} & \multicolumn{4}{|c|}{ Neotectonic activity (12 Ma) } & \multicolumn{8}{|c|}{ Neotectonic activity during } & \multirow{5}{*}{$\begin{array}{l}\text { Iat } \\
\text { Value } \\
\text { Class }\end{array}$} & \multirow{5}{*}{$\begin{array}{l}\text { Tectonic } \\
\text { Activity }\end{array}$} \\
\hline & & & & & \multicolumn{4}{|c|}{ Pleistocene (2.8 Ma) } & \multicolumn{4}{|c|}{ Holocene (11.7 ka) } & & \\
\hline & \multicolumn{2}{|c|}{ Subsidence } & \multicolumn{2}{|c|}{ Upward } & \multirow{2}{*}{\multicolumn{2}{|c|}{$\frac{\text { Subsidence }}{\text { Amount (m) }}$}} & \multicolumn{2}{|c|}{ Upward } & \multirow{2}{*}{\multicolumn{2}{|c|}{$\frac{\text { Subsidence }}{\text { Amount (m) }}$}} & \multicolumn{2}{|l|}{ Upward } & & \\
\hline & \multicolumn{4}{|c|}{ Rate $(\mathrm{cm} / 100$ years $)$} & & & & & & & & & & \\
\hline & Min. & Max. & Min. & Max. & Min & Max & Min & Max & Min & Max & Min & $\operatorname{Max}$ & & \\
\hline \multirow[t]{2}{*}{1} & 1000 & 1500 & $*$ & $*$ & 7.18 & 11.64 & $*$ & & 0.98 & 1.47 & $*$ & & 2.66 & $\mathbf{L}$ \\
\hline & 0.84 & 1.26 & & & & & & & & & & & 4 & \\
\hline \multirow[t]{2}{*}{2} & 1500 & & $*$ & $*$ & 11.64 & & $*$ & & 1.47 & & $*$ & & 2.66 & $\mathbf{L}$ \\
\hline & 1.26 & & & & & & & & & & & & 4 & \\
\hline \multirow[t]{2}{*}{3} & 1000 & 1500 & $*$ & $*$ & 7.18 & 11.64 & $*$ & & 0.98 & 1.47 & $*$ & & 2.30 & $\mathbf{M}$ \\
\hline & 0.84 & 1.26 & & & & & & & & & & & 3 & \\
\hline \multirow[t]{2}{*}{4} & 2000 & 2500 & $*$ & $*$ & 15.52 & 19.40 & $*$ & & 1.96 & 2.45 & $*$ & & 2.16 & $\mathbf{M}$ \\
\hline & 1.66 & 2.10 & & & & & & & & & & & 3 & \\
\hline \multirow[t]{2}{*}{5} & 2500 & & $*$ & $*$ & 19.40 & & $*$ & & 2.45 & & $*$ & & 2.16 & $\mathbf{M}$ \\
\hline & 2.10 & & & & & & & & & & & & 3 & \\
\hline \multirow[t]{2}{*}{6} & 750 & 1500 & $*$ & $*$ & 5.82 & 11.64 & $*$ & & 0.73 & 1.47 & $*$ & & 2.50 & $\mathbf{M}$ \\
\hline & 0.63 & 1.26 & & & & & & & & & & & 3 & \\
\hline \multirow[t]{2}{*}{7} & 1000 & 1500 & $*$ & $*$ & 7.18 & 11.64 & $*$ & & 0.98 & 1.47 & $*$ & & 2.16 & $\mathbf{M}$ \\
\hline & 0.84 & 1.26 & & & & & & & & & & & 3 & \\
\hline 8 & 1000 & 2500 & $*$ & $*$ & 7.18 & 19.40 & $*$ & & 0.98 & 2.45 & $*$ & & 2.66 & $\mathbf{L}$ \\
\hline & 0.84 & 2.10 & & & & & & & & & & & 4 & \\
\hline 9 & 2000 & 2500 & $*$ & $*$ & 15.52 & 19.40 & $*$ & & 1.96 & 2.45 & $*$ & & 2.30 & $\mathbf{M}$ \\
\hline & 1.66 & 2.10 & & & & & & & & & & & 3 & \\
\hline 10 & 0 & 2000 & 0 & 250 & 0 & 15.52 & 0 & 1.94 & 0 & 1.96 & 0 & 0.24 & 2.30 & $\mathbf{M}$ \\
\hline & 0 & 1.66 & 0 & 0.21 & & & & & & & & & 3 & \\
\hline 11 & 2000 & 3000 & $*$ & $*$ & 15.52 & 23.28 & $*$ & & 1.96 & 2.93 & $*$ & & 2.16 & $\mathbf{M}$ \\
\hline & 1.66 & 2.50 & & & & & & & & & & & 3 & \\
\hline 12 & 0 & 500 & 0 & 250 & 0 & 3.88 & 0 & 1.94 & 0 & 0.49 & 0 & 0.24 & 2.50 & $\mathbf{M}$ \\
\hline & 0 & 0.42 & 0 & 0.21 & & & & & & & & & 3 & \\
\hline 13 & 2000 & 2500 & $*$ & $*$ & 15.52 & 19.40 & $*$ & & 1.96 & 2.45 & $*$ & & 2.60 & $\mathbf{L}$ \\
\hline & 1.66 & 2.10 & & & & & & & & & & & 4 & \\
\hline 14 & 0 & 2500 & 0 & 250 & 0 & 19.40 & 0 & 1.94 & 0 & 2.45 & 0 & 0.24 & 2.00 & $\mathbf{H}$ \\
\hline & 0 & 2.10 & 0 & 0.21 & & & & & & & & & 2 & \\
\hline 15 & 3000 & & $*$ & $*$ & 23.28 & & $*$ & & 2.93 & & $*$ & & 2.50 & $\mathbf{M}$ \\
\hline & 2.50 & & & & & & & & & & & & 3 & \\
\hline 16 & 0 & 2500 & 0 & 250 & 0 & 19.40 & 0 & 1.94 & 0 & 2.45 & 0 & 0.24 & 2.30 & $\mathbf{M}$ \\
\hline & 0 & 2.10 & 0 & 0.21 & & & & & & & & & 3 & \\
\hline 17 & 2500 & 3000 & $*$ & $*$ & 19.40 & 23.28 & $*$ & & 2.45 & 2.93 & $*$ & & 2.30 & $\mathbf{M}$ \\
\hline & 2.10 & 2.50 & & & & & & & & & & & 3 & \\
\hline 18 & 0 & 2500 & 0 & 250 & 0 & 19.40 & 0 & 1.94 & 0 & 2.45 & 0 & 0.24 & 2.16 & $\mathbf{M}$ \\
\hline & 0 & 2.10 & 0 & 0.21 & & & & & & & & & 3 & \\
\hline
\end{tabular}


Table 3 continued

\begin{tabular}{|c|c|c|c|c|c|c|c|c|c|c|c|c|c|c|}
\hline \multirow{5}{*}{$\begin{array}{l}\text { Sub- } \\
\text { basin } \\
\text { No. }\end{array}$} & \multirow{2}{*}{\multicolumn{4}{|c|}{ Neotectonic activity (12 Ma) }} & \multicolumn{8}{|c|}{ Neotectonic activity during } & \multirow{5}{*}{$\begin{array}{l}\text { Iat } \\
\text { Value } \\
\text { Class }\end{array}$} & \multirow{5}{*}{$\begin{array}{l}\text { Tectonic } \\
\text { Activity }\end{array}$} \\
\hline & & & & & \multicolumn{4}{|c|}{ Pleistocene (2.8 Ma) } & \multicolumn{4}{|c|}{ Holocene (11.7 ka) } & & \\
\hline & \multicolumn{2}{|c|}{ Subsidence } & \multicolumn{2}{|c|}{ Upward } & \multirow{2}{*}{\multicolumn{2}{|c|}{$\frac{\text { Subsidence }}{\text { Amount (m) }}$}} & \multicolumn{2}{|c|}{ Upward } & \multirow{2}{*}{\multicolumn{2}{|c|}{$\frac{\text { Subsidence }}{\text { Amount (m) }}$}} & \multicolumn{2}{|c|}{ Upward } & & \\
\hline & \multicolumn{4}{|c|}{ Rate $(\mathrm{cm} / 100$ years $)$} & & & & & & & & & & \\
\hline & Min. & Max. & Min. & Max. & Min & Max & Min & $\operatorname{Max}$ & Min & Max & Min & Max & & \\
\hline \multirow[t]{2}{*}{ Average } & 1125 & 2166 & 0 & 69.44 & 9.463 & 15.522 & 0 & 0.538 & 1.21 & 2.58 & 0 & 0.067 & 2.35 & $\mathbf{M}$ \\
\hline & 0.937 & 1.805 & 0 & 0.578 & & & & & & & & & 3 & \\
\hline
\end{tabular}

Bold indicates the rate or subsidence or upward movements $(\mathrm{cm} / 100$ years)

The recorded upward and downward movements are in meter

*Means no upward movement

$H$ high, $M$ moderate, $L$ low

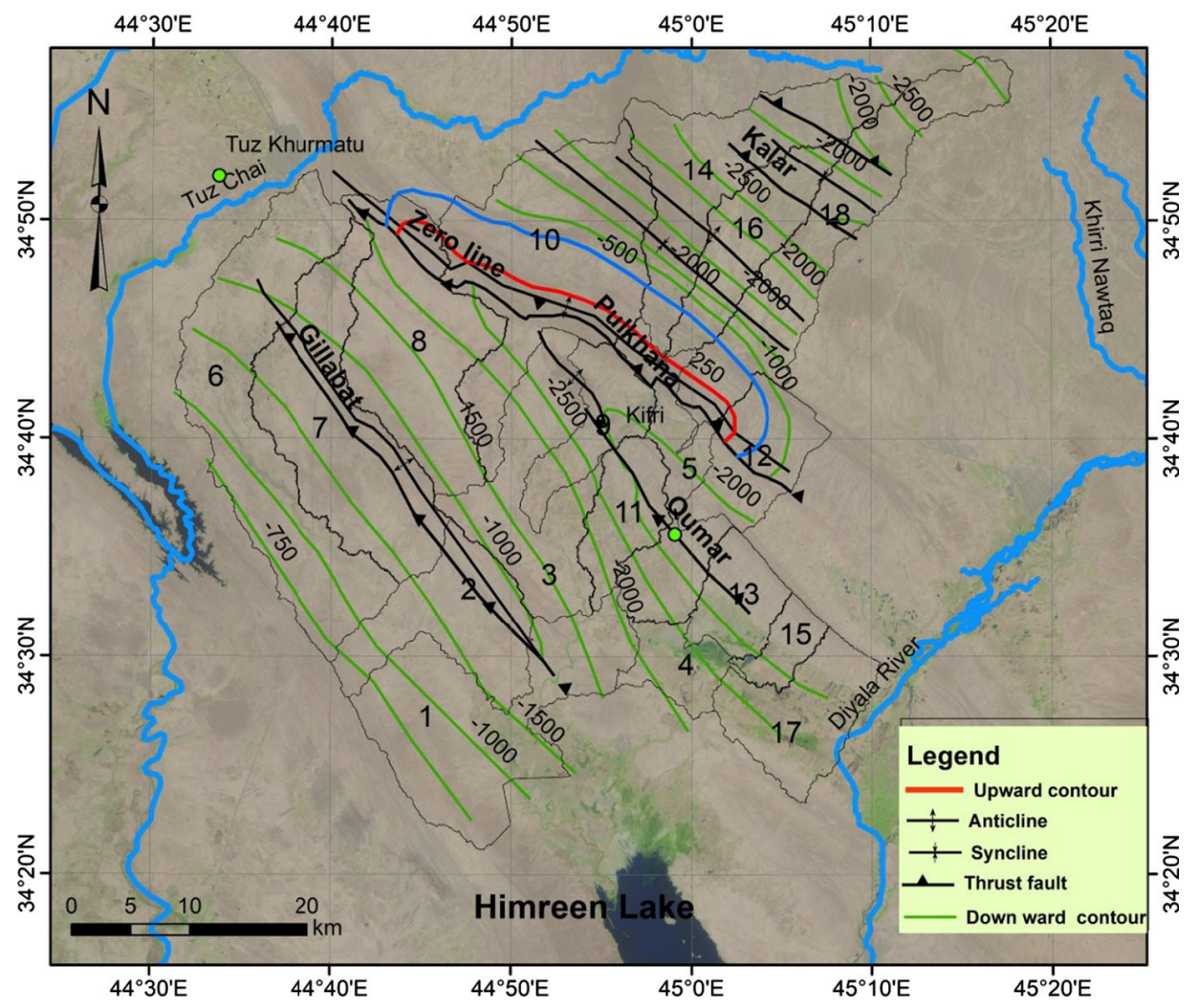

Fig. 7 Neotectonic map of the studied four sub-basins. (Modified from Sissakian and Deikran 1998). The background is Sentinel image

The amounts and rates of the subsidence and/or upward movements, during the Neotectonic Period, and the Iat values and tectonic activity class in each of the eighteen sub-basins are assigned in Table 3. Moreover, the subsidence and upwards amounts were calculated during the Pleistocene (2.8 Ma) and the Holocene (11.7 Ka) (ICS 2012) in the eighteen sub- basins (Table 3 ). The amount of the subsidence during the Neotectonic period, Pleistocene and Holocene range from (0-3000), (0-23. 28) to $(0-2.93) \mathrm{m}$, respectively. Whereas the amount of the upward movement during the three intervals range (0-250), $(0-1.94)$ and $(0-0.24) \mathrm{m}$, respectively. The subsidence 
and upward rates during the Neotectonic period range $(0-2.5)$ and $(0-0.21) \mathrm{cm} / 100$ year, respectively.

Those sub-basins which exhibit wide range of subsidence, the Iat values indicate High tectonic activity (Sub-basin No. 14) or Medium tectonic activity, but with Iat value of 2.16 which is very close to Class 2 (for example Sub-basin No. 18).

The subsidence amount depends on the thickness of the exposed formations younger than the Fatha Formation which forms the beginning of the Neotectonic phase in Iraq. The thicknesses of the Injana, Mukdadiya and Bai Hassan formations which overlie the Fatha Formation are considered in the construction of the Neotectonic map of Iraq (Sissakian and Deikran 1998). The thicknesses are highly variable in the area; therefore, any miss-estimation of the thicknesses will give subsidence wrong amount of subsidence. This may be the case with Sub-basin No. 4.

\section{Results}

The acquired data of the six studied geomorphic indices showed that the average Iat value in Kifri Chai Basin is 2.35, which means Class 3; meaning that the Relative Tectonic Activity in the basin is Moderate (Table 2). Moreover, the regional Neotectonic activity data showed that there is positive relation with the relative tectonic activity in Kifri Chai Basin.

\section{Discussion}

The tectonic activity and the values of each of the six geomorphic indices are discussed showing the main differences and the reasons for similarities and/or anomalous results within the eighteen sub-basins. The average value of tectonic activity indicator (Iat) in the eighteen sub-basins is $\mathbf{2 . 3 5}$ (Tables 2, 4), which indicates Class 3 and means that the tectonic activity is Moderate. Accordingly, the tectonic activity of Kifri Chai Basin is Moderate.

The prevalence of the Medium tectonic activity in Kifri Chai Basin (Tables 2, 3, 4, and Fig. 6, Right) is attributed to the following reasons: (1) The exposed rocks within the eighteen sub-basins are mainly clastics, with exception of the Fatha Formation, which includes gypsum and limestone beds with thick claystone beds and thin sandstone beds. Although the Fatha Formation is exposed only in Sub-basins No. 5, 8, 9 and 10 and a very small part in Sub-basin No. 11 (Fig. 2), but the coverage area is very small, along the thrust of Pulkhana anticline only (Fig. 2); therefore, the presence of both rock types does not affect significantly the geomorphological indices as compared to the clastic rocks which cover the majority of the basin, (2) Tectonically, the eighteen sub-basins are located within the Low Folded Zone (Fouad 2012); therefore, have influenced by the same tectonic stresses during the past geological time, (3) The average of the Mountain Front index values is 1.8 (Tables 1,2), which means Moderate class, but, within Sub-basins No. 3, 5, 8, 9, 12, 13, 15 and 17 is High Class (Table 1). This means in those sub-basins the tectonic activity was higher. Otherwise the Mountain Front index value wouldn't be High, (4) The eighteen sub-basins are covered mainly by clastic rocks (Sissakian and Fouad 2014, Barwary and Slewa 2014a, b), and are under the same climatic conditions, as the annual rain fall and temperature are concerned; therefore, the shape, size and orders of the valleys are almost the same. Accordingly, the $\boldsymbol{S L}, \boldsymbol{A f}, \boldsymbol{B s}, \mathbf{H i}$ and Vf values (Table 1) are uniform and exhibit almost the same classes. However, few exceptions

Table 4 Statistical data about the classes of the geomorphic indices and Iat

\begin{tabular}{|c|c|c|c|c|c|c|c|c|}
\hline \multirow[t]{2}{*}{ Class } & \multicolumn{6}{|c|}{ Geomorphic indices (Scored numbers in sub-basins) } & \multicolumn{2}{|c|}{ Tectonic activity } \\
\hline & $\mathrm{Sl}$ & Af & Bs & $\mathrm{Hi}$ & Vf & Smf & Class & Grade \\
\hline 1 & 3 & 3 & 7 & $*$ & $*$ & 9 & 1 & High \\
\hline 2 & 1 & 8 & 3 & 1 & 1 & 5 & 13 & Moderate \\
\hline 3 & 14 & 7 & 8 & 17 & 17 & 2 & 4 & Low \\
\hline Total & 18 & 18 & 18 & 18 & 18 & $16^{* * *}$ & 18 & \\
\hline
\end{tabular}

*No class exists

**No Mountain front exist in 2 sub-basins 
occur, especially in $\boldsymbol{H i}$ and $\boldsymbol{V} \boldsymbol{f}$ values (Table 2). All the sub-basins have the same class in both indices; Class 3, except Sub-basin No. 11 and 10, respectively which have Class 2 (Table 2). These exceptional values do not influence significantly on the average results of the acquired values.

The Af, Bs and Smf indices are distributed over the three main classes of El-Hamdouni et al. (2008) (Table 2).This is attributed to: (1) Locally, hard and massive beds of conglomerate and/or sandstone may influence on the shape of the valleys and their width and depths; accordingly, different results are acquired at different parts in the same sub-basins, (2) The dip amount of the exposed rocks may also influence on the symmetry of the valleys, especially when a valley runs parallel to the main strike of the exposed rocks, the exposed rocks on both sides may have different dip amounts; accordingly, the valley will show different symmetry, and (3) Locally, soft and thick claystone beds, especially in the Bai Hassan Formation will exhibit flat or gently sloping areas within a certain subbasin; accordingly, the acquired values will differ from the acquired values of other indices. The values of $\mathbf{S I}$ index are also distributed over the classes with the majority being of Class 3 (Table 2), which means Low tectonic activity. This can be attributed to the prevailing of the clastic rocks in the sub-basins; therefore, the grade and rate of the weathering and erosion will be almost the same. Accordingly, the ratio of the valley length to its width will be almost the same; with few exceptions due to the presence of different rock types; rather than the clastics.

\section{Conclusions}

The Kifri Chai Basin is divided into eighteen subbasins depending on the 4th, 5th and 6th stream orders to indicate the tectonic activity in the main basin. The tectonic activity is acquired by indicating the six geomorphologic indices that lead to the value of the tectonic activity (Iat). To indicate the values of the six indices, the required data were measured at each subbasin using ArcGIS technique, the numerical data is acquired from the DEM.

The tectonic activity of each sub-basin is indicated; accordingly, the average tectonic activity of the Kifri Chai Basin is indicated. A Moderate tectonic activity is assigned to the Kifri Chai Basin; because the average Iat value is found to be 2.35, which assigns to Class 3 and means Moderate tectonic activity.

The regional Neotectonic activity is compared with the relative tectonic activities in the eighteen subbasins. Generally, there is a fair relation between the two comparatives; especially the subsidence amounts and the scored relative tectonic activity value (Iat), especially, when the range of the subsidence in a certain sub-basin is high.

Acknowledgements The authors express their sincere thanks to Iraq Geological Survey (GEOSURV, Iraq) for submitting relevant data which were used in the current research work. Moreover, for supplying satellite and images and geological maps. Thanks are extended to Dr. Arsalan O. Al-Jaf (GEOSURV, Iraq) for his critical discussions which amended the manuscript.

Open Access This article is distributed under the terms of the Creative Commons Attribution 4.0 International License (http:// creativecommons.org/licenses/by/4.0/), which permits unrestricted use, distribution, and reproduction in any medium, provided you give appropriate credit to the original author(s) and the source, provide a link to the Creative Commons license, and indicate if changes were made.

\section{References}

Arrowsmith JR, Zielke O (2009) Tectonic geomorphology of the San Andreas Fault Zone from high-resolution topography: an example from the Cholame segment. Geomorphology 113(1):70-81

Atomenergoexport (1985) Feasibility study of site selection for nuclear power plant location in Iraq, Book 3. Iraqi Atomic Energy Commission Library, Baghdad, p 233

Barwary AM, Slewa NA (2014a) Geological map of Khanaqeen Quadrangle, scale 1:250000, 2nd edn. Iraq Geological Survey Publications, Baghdad

Barwary AM, Slewa NA (2014b) Geological map of Samarra Quadrangle, scale 1:250000, 2nd edn. Iraq Geological Survey Publications, Baghdad

Bull WB, McFadden L (1977) Tectonic geomorphology north and south of the Garlock Fault, California, Geomorphology in Arid regions. In: Doehring DO (ed) Publications in geomorphology. State University of New York at Binghamton, New York, pp 115-138

Burbank DW (1992) Causes of recent Himalayan uplift deduced from deposited patterns in the Ganges basin. Nature 357:680-682

Burbank DW, Anderson RS (2001) Tectonic geomorphology. Blackwell Scientific Publications, Oxford, p 274

Crosby BT, Sheehan D (2006) Tectonics from topography: procedures, promise, and pitfalls. Geol Soc Am 398:55-74

Cuong NQ, Zuchiewicz WA (2001) Morphotectonic properties of the Lo river fault near Tam Dao in North Vietnam. Nat Hazards Earth Syst Sci 1:15-22

Dehbozorgi M, Pourkermani M, Arian M, Matkan AA, Motamedi H, Hosseiniasl A (2010) Quantitative analysis of 
relative tectonic activity in the Sarvestan area, central Zagros, Iran. Geomorphology 121(3):329-341

El-Hamdouni R, Irigaray C, Fernández T, Chacón J, Keller EA (2008) Assessment of relative active tectonics, southwest border of the Sierra Nevada (southern Spain). Geomorphology 96:150-173

Fisher DM, Gardner TW, Marshall JS, Sak PB, Protti M (1998) Effect of subducting sea-floor roughness on fore-arc kinematics, Pacific coast, Costa Rica. Geology 26(5):467-470

Fouad SF (2012) Tectonic map of Iraq, scale 1:1000 000, 3rd edn. Iraq Geological Survey Publications, Baghdad

Gasparini NM, Whipple KX (2014) Diagnosing climatic and tectonic controls on topography: eastern flank of the northern Bolivian Andes. Lithosphere 6(4):230-250

Ghassemi MR (2005) Drainage evolution in response to fold growth in the hanging-wall of the Khazar fault, northeastern Alborz, Iran, Basin. Res J 17:425-436

Gürbüz A, Gürer ÖF (2008) Tectonic geomorphology of the North Anatolian fault zone in the Lake Sapanca Basin (Eastern Marmara Region, Turkey). Geosci J 12(3):215-225

Habibi A, Gharibreza M (2015) Estimation of the relative active tectonics in Shahriary basin (Central Iran) using geomorphic and seismicity indices. Nat Environ Change 1(1):71-83

Hack JT (1973) Stream-profiles analysis and stream-gradient index. J Res US Geol Surv 1:421-429

Hare PW, Gardner TW (1985) Geomorphic indicators of vertical neotectonism along converging plate margins, Nicoya Peninsula, Costa Rica. In: Morisawa M, Hack JT (eds) Tectonic Geomorphology: proceedings of the 15th geomorphology symposia series, Binghamton, pp 76-104

ICS (International Commission on Stratigraphy) (2012) International chronological chart. IGC, Brisbane, p 34

Keller EA, Pinter N (2002) Active tectonics: earthquakes, uplift, and landscape, 2nd edn. Prentice Hall, Upper Saddle River, p 359

Keller EA, Bonkowski MS, Korsch RJ, Shlemon RJ (1982) Tectonic geomorphology of the San Andreas fault zone in the southern Indio hills, Coachella valley, California. Geol Soc Am Bull 93(1):46-56

Kirby E, Whipple KX (2012) Expression of active tectonics in erosional landscapes. J Struct Geol 44:54-75. https://doi. org/10.1016/j.jsg.2012.07.009

Kirby E, Whipple KX, Tang W, Chen Z (2003) Distribution of active rock uplift along the eastern margin of the Tibetan Plateau: inferences from bedrock channel longitudinal profiles. J Geophys Res 108(B4):2217. https://doi.org/10. 1029/2001jb000861

Mayer L (1990) Introduction to quantitative geomorphology: an exercise manual. Prentice Hall, Englewood Cliffs, p 380

Merritts D, Vincent KR (1989) Geomorphic response of coastal streams to low, intermediate, and high rates of uplift, Medocino triple junction region, northern California. Geol Soc Am Bull 101(11):1373-1388

Morell KD, Fisher DM, Gardner TW (2008) Inner fore-arc response to subduction of the Panama Fracture Zone, southern Central America. Earth Planet Sci Lett 265:82-95

Mosavi EJ, Arian M (2015) Tectonic geomorphology of Atrak River, NE Iran. Open J Geol 5:106-114

Mumipour M, Najad HT (2011) Tectonic geomorphology setting of Khayiz anticline derived from GIS processing, Zagros mountain, Iran. Asian J Earth Sci 4(3):1711-1782
Obruchev VA (1948) Neotectonics. In: Fairbridge RW (ed) 1968. Encyclopaedia of geomorphology. Dowden, Hutchinson and Ross Inc., Pennsylvania

Pike RI, Wilson SE (1971) Elevation-relief ratio, hypsometric integral, and geomorphic area altitude analysis. Bull Geol Soc Am 82:1079-1084

Ramirez-Herrera MT (1998) Geomorphic assessment of active tectonics in the Acambay Graben, Mexican volcanic belt. Earth Surf Proc Land 23:317-332

Ramsey LA, Walker RT, Jackson J (2008) Fold evolution and drainage development in the Zagros mountains of Fars province, SE Iran. Basin Res 20:23-48

Rehak K, Strecker MR, Echtler HP (2008) Morphotectonic segmentation of an active forearc, $37-41^{\circ} \mathrm{S}$, Chile. Geomorphology 94(1-2):98-116

Rockwell TK, Keller EA, Johnson DL (1985) Tectonic geomorphology of alluvial fans and mountain fronts near Ventura, California. In: Proceedings of 15th annual geomorphology symposium. Tectonic Geomorphology, Boston, pp 183-207

Sissakian VK (1978) Report on the regional geological survey of the Tuz Khurmatu, Kifri and Kalar Area. Iraq Geological Survey Library Report No. 131, 111 pp

Sissakian VK, Deikran DB (1998) Neotectonic map of Iraq, scale 1:1000000. Iraq Geological Survey Publications, Baghdad

Sissakian VK, Fouad SF (2014) Geological map of Sulaimaniyah Quadrangle, scale 1:250000, 2nd edn. Iraq Geological Survey Publications, Baghdad

Strahler AN (1952) Hypsometric (area-altitude) analysis of erosional topography. Geol Soc Am Bull 63:1117-1142

Toudeshki VH, Arian M (2011) Morphotectonic analysis in the Ghezel Ozan river basin, NW Iran. J Geogr Geol 3:258-265

Verrios S, Zygouri V, Kokkalas S (2004) Morphotectonic analysis in the Eliki fault zone (Gulf of Corinth, Greece). Bulletin of the Geological Society of Greece, Vol. XXXVI. In: Proceedings of the 10th international congress, Thessaloniki, pp 1706-1715

Wells SG, Bullard TF, Menges CM, Drake PG, Karas PA, Kelson KI, Ritter JB, Wesling JR (1988) Regional variations in tectonic geomorphology along a segmented convergent plate boundary, Pacific coast of Costa Rica. Geomorphology 1:239-265

Wobus CW, Tucker GE, Anderson RS (2010) Does climate change create distinctive patterns of landscape incision. J Geophys Res 115(F04008):1-12

Wobus C, Whipple KX, Kirby E, Snyder N, Johnson J, Spyropolou K, Kirby E, Whipple KX (2012) Expression of active tectonics in erosional landscapes. J Struct Geol 44:54-75

Youkhanna RY, Hradecky P (1978) Report on regional geological mapping of Khanaqin-Maidan Area. Iraqi Geological Survey Library Report No. 903

Publisher's Note Springer Nature remains neutral with regard to jurisdictional claims in published maps and institutional affiliations. 